\title{
Vesicular stomatitis virus (VSV) as a paradigm for predicting antiviral activity against Ebola virus (EBOV)
}

\author{
Erik De CLERCQ
}

\begin{abstract}
There are at present no antivirals available which have been formally licensed for clinical use for the treatment of Ebola virus (EBOV) infections in humans. The most advanced to be approved for this purpose is favipiravir (T-705), a viral RNA polymerase inhibitor. Under consideration are BCX4430, also a viral RNA polymerase inhibitor, and 3-deazaneplanocin A and various other S-adenosylhomocysteine (SAH) hydrolase inhibitors. A number of compounds which have been approved for other purposes seem to interact with the cell entry of
\end{abstract}

EBOV. Some compounds like pyrazofurin have been found to be exquisitely potent inhibitors of vesicular stomatitis virus (VSV). VSV belongs to the rhabdoviridae, a family closely related to the family of the filoviridae to which EBOV and Marburg virus belong. VSV, unlike EBOV and Marburg virus which require biosafety level 4 , can be handled in conventional safety conditions.

Key words: Ebola virus (EBOV); vesicular stomatitis virus (VSV); rhabdoviridae; filoviridae; favipiravir; BCX4430; pyrazofurin; SAH hydrolase
Erik De Clercq

Rega Institute for Medical Research, KU Leuven, Minderbroedersstraat 10, B-3000 Leuven, Belgium

Correspondence:

E. De CLERCQ

E-mail: erik.declercq@rega.kuleuven.be

\section{INTRODUCTION}

Interferon was originally considered as the panacea for the treatment of virus infections, just as antibiotics and particularly penicillin had proved to be the case for bacterial infections. Initially, there were two approaches for the clinical use of interferon: exogenous and endogenous. Exogenous use of interferon was originally not very practical because of the limited amounts of exogenous interferon available. Thus, the main emphasis was put on the endogenous induction of interferon, and viruses would initially seem as the best choice for this purpose (as after all, Isaacs and Lindenmann had discovered interferon) (1) by using influenza virus as the inducer. To verify whether the induced antiviral substance was interferon, an assay system had to be developed that could quantitate the amount of interferon induced by any putative inducer, and for this titration, a challenge virus had to be used which in the early interferon days was either vaccinia virus (VV) or vesicular stomatitis virus (VSV). The first belongs to the poxviridae (with variola virus (smallpox) as the prototype), the second 

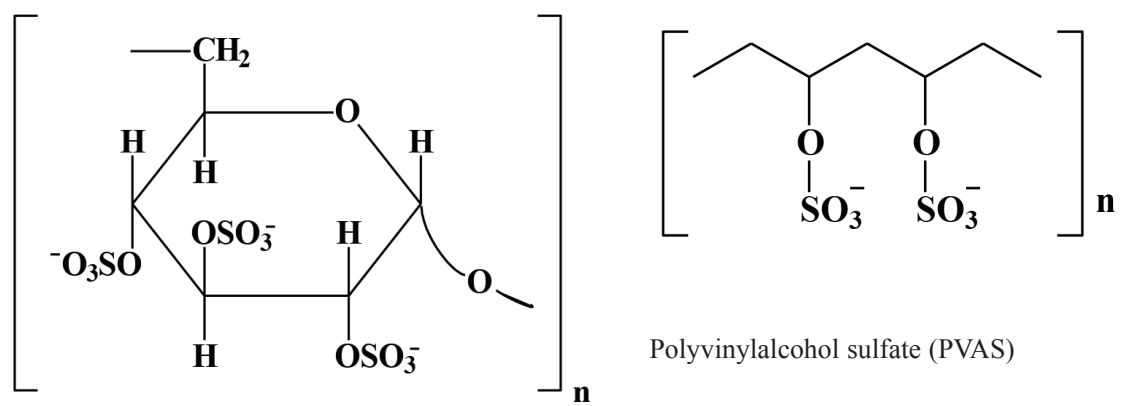

Polyvinylalcohol sulfate (PVAS)

Dextran sulfate

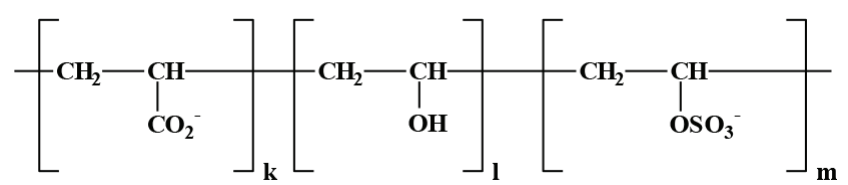

Polyacrylic acid-vinylalcohol sulfate (PAVAS) copolymer

Fig. 1. Sulfated polysaccharides.

to the rhabdoviridae (with rabies virus as the prototype). In the 1960s, when I started my career with Prof. Piet De Somer as my mentor, Ebola and Marburg had not yet been discovered: Ebola virus (EBOV) was first isolated by Pattyn et al. in 1976 (2), that is 5 years before AIDS would be identified as a well-defined disease (the viral origin of this disease would be identified two years later, in 1983). In the late 1960's, Maurice Hilleman's group at Merck found that interferon could be induced by double-stranded RNAs [i.e. poly(I).poly(C)]; Tom Merigan at Stanford found that interferon could be induced by a synthetic polyanion (pyran copolymer) and, in De Somer's Laboratory I found another synthetic polyanion (polyacrylic acid) as inducer of interferon. In 1968, I published, with my mentor as co-author, that both interferon and polyacrylic acid could protect newborn mice against a lethal VSV infection (3). Little I knew that almost 50 years later this observation could serve as a paradigm for an epidemic, Ebola, that would lead to a death toll of more than 10,000 victims in West Africa, and spread fear and concern over the whole world.

\section{INTERFERON}

Whenever a new virus infection emerges, or re-emerges, so does the interest in using interferon to combat this infection. This was the case in 2003 when SARS (severe acute respiratory syndrome) emerged (4), and it happened again with the current EBOV outbreak (5). In fact, interferon- $\beta$ newborn mice (3).

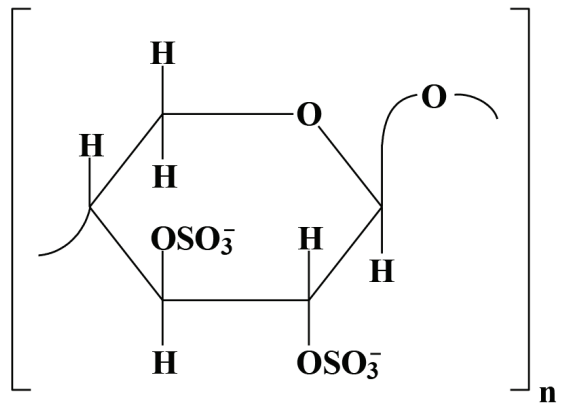

Pentosan (poly)sulfate

therapy was shown to prolong the survival of rhesus macaques infected with either EBOV or Marburg virus (5). The use of interferon, and, in particular, pegylated interferon, to curtail the current EBOV epidemic should be facilitated by its increased availability now that its usefulness in the treatment of hepatitis $\mathrm{C}$ virus infections is dwindling down because of the growing impact of directacting antivirals (DAAs) to treat $\mathrm{HCV}$ infections. That interferon may be effective in the treatment of EBOV infections could somehow be presaged by the protective effects noted, now almost 50 years ago, by interferon and its inducers (i.e. polyacrylic acid) against VSV infection in

\section{SULFATED POLYSACCHARIDES (Fig. 1)}

Sulfated polysaccharides have been identified as potent and selective inhibitors of various enveloped viruses, in particular HIV, but also VSV (6). The prototype of this family is dextran sulfate, but mannan sulfate has proven almost 10-fold more potent against VSV in this respect (7). Pentosan polysulfate was described by Baba et al. (8) as a potent and selective HIV inhibitor. Dextran sulfate was first shown to be inhibitory to the replication of HIV in 1987 by Ueno and Kuno (9) and Ito et al. (10). Still in 1988, Baba and his coworkers (6) confirmed that the antiviral activity of sulfated polysaccharides included VSV, and that, as specifically shown for dextran sulfate, its inhibitory effect on HIV was due to the inhibition of virus binding (adsorption) to the cells (11), an observation that had been independently made by Mitsuya et al. (12) as well. Schols et al. (13) further described sulfated polymers such as PVAS (polyvinylalcohol sulfate) and its copolymer with polyacrylic acid (PAVAS) as potent and selective inhibitors of various enveloped viruses such as HSV, CMV, VSV, $\mathrm{RSV}$, and toga-, arena- and retroviruses (including HIV). For dextran sulfate, inhibition of VSV replication was shown within a molecular weight range of 5,000 to 500,000 
<smiles>NC(=O)c1ncn(C2OC(CO)C(O)C2O)n1</smiles>

Ribavirin

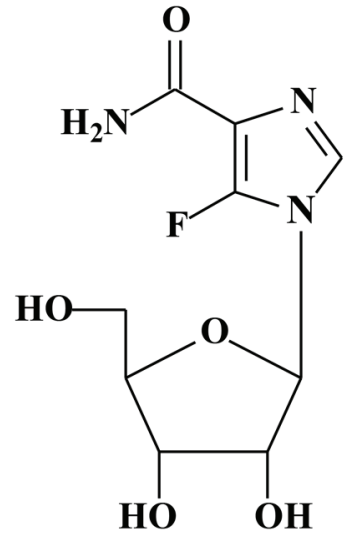

FICAR<smiles>C#Cc1c(C(N)=O)ncn1C1OC(CO)C(O)C1O</smiles>

Fig. 2. IMP dehydrogenase inhibitors.
(14); curiously, heparin, while active against HIV, did not prove inhibitory to VSV (14). Antiviral activity against HIV and other enveloped viruses, including VSV, was later shown with a variety of sulfated polysaccharides extracted from seaweeds $(15,16)$. It is obvious that all sulfated polymers, irrespective of their origin (synthetic or biologic), because of their activity against VSV, would deserve to be further evaluated for their activity against filoviruses such as EBOV. This advice may also be extended to the polyanionic (i.e. polysulfonate) dendrimers, which were found inhibitory to HIV but not evaluated against VSV (17).

\section{IMP DEHYDROGENASE INHIBITORS (Fig. 2)}

It is not evident that the IMP dehydrogenase (which converts IMP to XMP, that is then converted to GMP and thus replenishes the intracellular GTP pools) is an appropriate target for potential anti-VZV and/or -EBOV agents. Ribavirin [which has been identified in 1972 as a broad-spectrum antiviral agent $(18,19)]$ is targeted at the IMP dehydrogenase (20), but it has only modest activity against VSV (21) and little or no activity against EBOV (22). Introduction of a fluorine in the imidazole moiety of the heterocyclic ring, thus resulting in the formation of FICAR (5-fluoro-1- $\beta$-D-ribofuranosylimidazole-4carboxamide) decreases the anti-VSV potency of ribavirin (1- $\beta$-D-ribofuranosyl-1,2,4-triazole-4-carboxamide) (21), but introduction of a 5-ethynyl function as in EICAR (5-ethynyl-1- $\beta$-D-ribofuranosylimidazole-4-carboxamide) markedly increases the anti-VSV potency (curiously, EICAR was found to inhibit VSV replication in HeLa cells at $4 \mu \mathrm{g} / \mathrm{ml}$, while it was inactive against VSV in primary rabbit kidney (PRK) cells (23). Being an IMP dehydrogenase inhibitor, EICAR, like ribavirin, may not be primarily directed to the treatment of virus infections (HCV is an apparent exception, but here ribavirin is mainly acting as an immunosuppressive rather than antiviral agent). EICAR was originally envisaged as an anti-leukemic agent (24). Its potent inhibitory effect on IMP dehydrogenase (25) may point to its role as an immunosuppressive agent.

\section{CYCLOPENTYL CYTOSINE (CARBODINE) AND CYCLOPENTENYL CYTOSINE (Fig. 3)}

At a certain time, about 25 years ago, carbodine (carbocyclic cytidine, C-Cyd) (26) and cyclopentenyl cytosine, Ce-Cyd (27) generated much interest as broad-spectrum antiviral agents. With an $\mathrm{IC}_{50}$ of $0.7 \mu \mathrm{g} / \mathrm{ml}$ (Ce-Cyd) and $4 \mu \mathrm{g} / \mathrm{ml}$ (C-Cyd) against VSV (in PRK cells), this activity also extended to the family of the rhabdoviruses, which, again, could herald activity against the filovirus EBOV. Moreover,

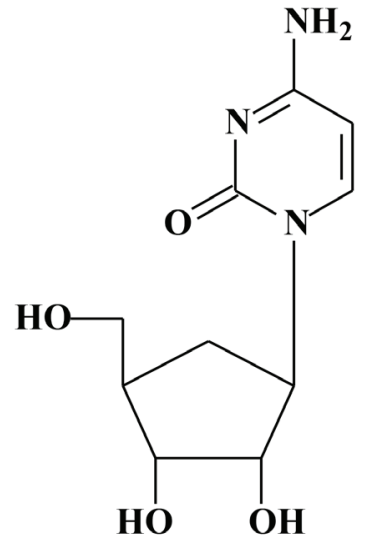

C-Cyd

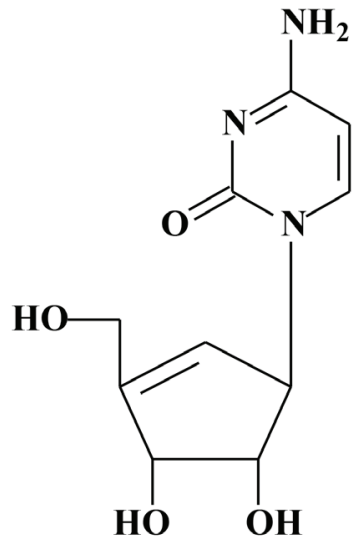

Ce-Cyd
Fig. 3. Cyclopentyl and cyclopentenyl cytosine. 
<smiles>Nc1ncnc2c1ncn2C1OC(CO)C(O)C1O</smiles>

Ara-A

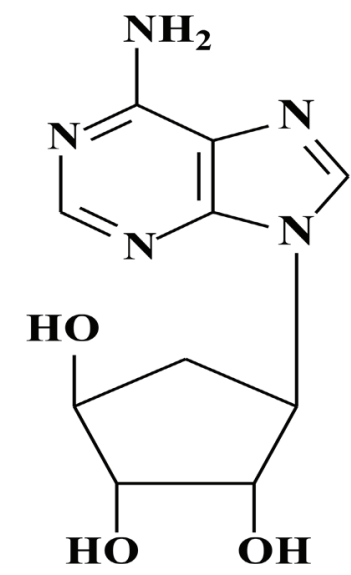

5'-nor-C-Ado

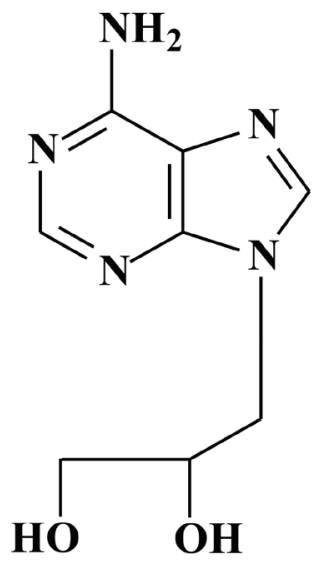

(S)-DHPA

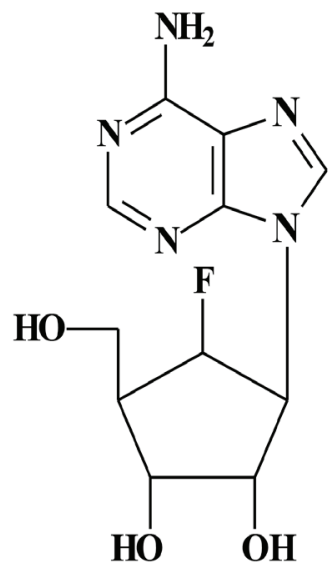

F-C-Ado<smiles>Nc1ncnc2c1ccn2C1OC(CO)C(O)C1O</smiles>

Tubercidin

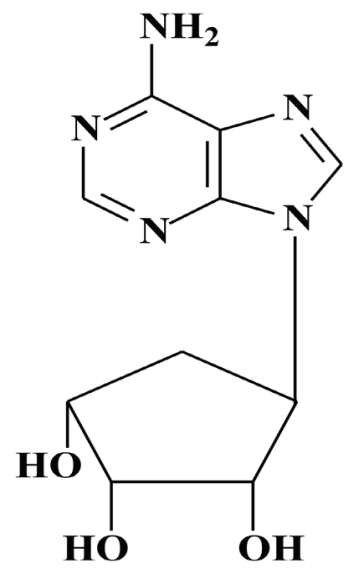

Epimer of (-)-5'-noraristeromycin

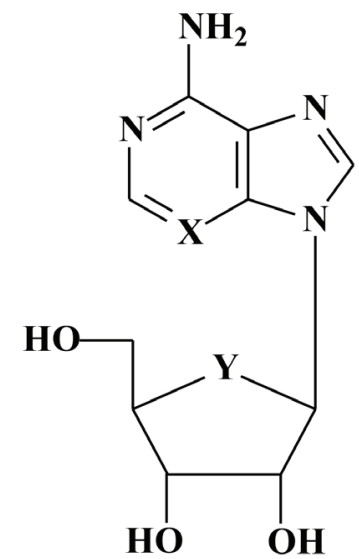

C-Ado $(\mathrm{X}=\mathrm{N}, \mathrm{Y}=\mathrm{O})$

c3Ado $(\mathrm{X}=\mathrm{CH}, \mathrm{Y}=\mathrm{O})$

$\mathrm{C}$-c3Ado $(\mathrm{X}=\mathrm{CH}, \mathrm{Y}=\mathrm{CH} 2)$

Fig. 4. Adenosine analogues.

C-Cyd and Ce-Cyd are targeted at the CTP synthetase, which converts UTP to CTP, and thus plays an important role in de novo biosynthesis of pyrimidine mononucleotides. This role could be considered as additive to the antiviral or antimetabolic action of pyrazofurin which is targeted at OMP decarboxylase that converts OMP to UMP, and thus interferes with a step higher up in de novo biosynthesis of pyrimidine mononucleotides. Pyrazofurin has been found to be extremely potent in inhibiting VSV replication.

\section{SAH HYDROLASE: ADENOSINE ANALOGUES}

\section{(Fig. 4)}

Vidarabine (ara-A) has been known for half of a century as an antiviral agent specifically active against DNA viruses such as herpes simplex virus and vaccinia virus $(28,29)$. The fact that it exhibited some activity against a (-)RNA virus, VSV (30) was therefore considered as a curiosum, and so was the anti-VSV activity of $(S)-9-(2,3-$ dihydroxypropyl)adenine [(S)-DHPA] (31). However, the discovery of 3-deazaadenosine ( $\mathrm{c}^{3} \mathrm{Ado}$ ), the carbocyclic analogue of adenosine (C-Ado) and 3-deazaadenosine (C- $\mathrm{c}^{3} \mathrm{Ado}$, which had all three been recognized as S-adenosylhomocysteine (SAH) hydrolase inhibitors, confirmed that all these compounds acted against VSV by inhibiting the SAH hydrolase (32), and, in fact, a close correlation was found between the anti-VSV activity and SAH hydrolase inhibition (33). Tubercidin (7-deazaadenosine, $\mathrm{c}^{7}$ Ado) was not included in this comparative study: it proved extremely potent (minimal inhibitory concentration (MIC): $0.0007 \mu \mathrm{g} / \mathrm{ml}$ ) in its antiVSV activity, but also quite cytotoxic $(0.4 \mu \mathrm{g} / \mathrm{ml})(34,35)$. Tubercidin and its related analogues toyocamycin and sangivamycin must have various effects other than SAH hydrolase inhibition pertaining to their cytotoxicity. In addition to tubercidin, toyocamycin and sangivamycin, C-nucleoside analogue, formycin, may seem too toxic to be further explored from an antiviral viewpoint $(36,37)$. 


\section{SAH HYDROLASE: NEPLANOCIN ANALOGUES} (Fig. 5)

With the discovery of neplanocin A or (-)-9-[(trans-2,trans3-dihydroxy-4-(hydroxymethyl)cyclopent-4-enyl]adenine, 3-deazaneplanocin A and their 5'-nor derivatives, 9-(trans2',trans-3'-dihydroxycyclopent-4'-enyl)adenine (DHCeA) and 9-(trans-2',trans-3'-dihydroxycyclopent-4'-enyl)-3deazadenine ( $\left.\mathrm{c}^{3} \mathrm{DHCeA}\right)(38,39)$, the link between SAH hydrolase inhibition and antiviral activity, especially against VSV, was clearly corroborated, and again, a close correlation was found between inhibition of SAH hydrolase and anti-VSV activity $(40,41)$. In the latter article, I postulated that the viruses proven particularly sensitive to inhibition by SAH hydrolase inhibitors were the poxviridae, paramyxoviridae, rhabdoviridae (including rabies, infectious hematopoietic necrosis virus, and VSV) and reoviridae. Ten years later, Bray would demonstrate that

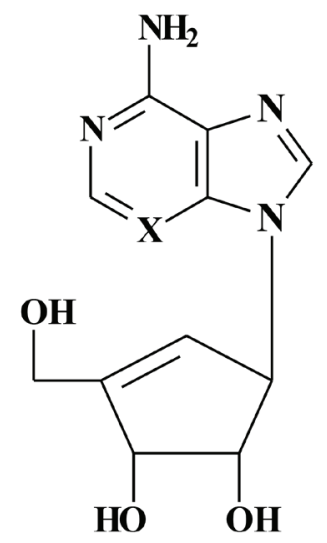

Neplanocin $\mathrm{A}(\mathrm{X}=\mathrm{N})$ 3-Deazaneplanocin $\mathrm{A}(\mathrm{X}=\mathrm{CH})$

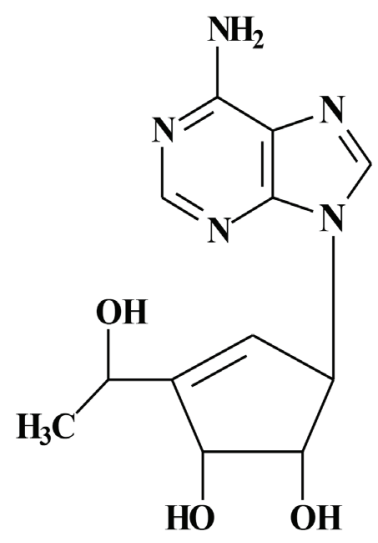

6'R)-6'-C-methylneplanocin A

Fig. 5. Neplanocin analogues.

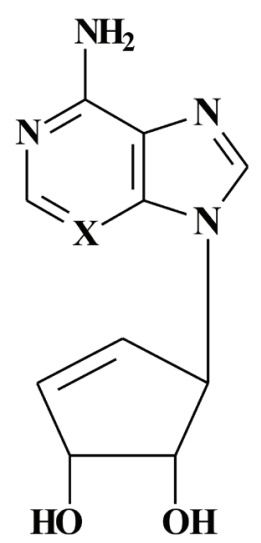

$\operatorname{DHCeA}(\mathrm{X}=\mathrm{N})$ c3DHCeA $(\mathrm{X}=\mathrm{CH})$

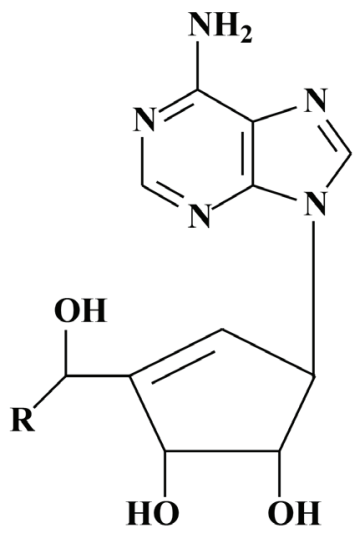

(6'R)-6'-C-ethylneplanocin $\mathrm{A}\left(\mathrm{R}=\mathrm{CH}_{2} \mathrm{CH}_{3}\right)$

(6'R)-6'-C-ethenylneplanocin $\mathrm{A}\left(\mathrm{R}=\mathrm{CH}=\mathrm{CH}_{2}\right)$

(6'R)-6'-C-ethynylneplanocin $\mathrm{A}(\mathrm{R}=\mathrm{C} \equiv \mathrm{CH})$ 3-deazaneplanocin A was exquisitely active, in vivo, against EBOV $(42,43)$. In addition to neplanocin $A$ and 3-deazaneplanocin $\mathrm{A}\left(\mathrm{MIC}_{50}: 0.07 \mu \mathrm{g} / \mathrm{ml}\right.$ for VSV), various other aristeromycin and neplanocin $\mathrm{A}$ analogues are active against VSV at an MIC of circa $0.1 \mu \mathrm{g} / \mathrm{ml}$ : $( \pm) 5^{\prime}$-noraristeromycin (44), (-)5'-noraristeromycin $(45,46)$, and 3-deaza-5' -noraristeromycin (46); (6' $R)-6^{\prime}-C$ methylneplanocin A (47), (6'R)-6'-C-ethenyl (or ethynyl) neplanocin A (48); $( \pm)-6$ ' $\beta$-D-fluoroaristeromycin (F-CAdo) (49); and epi(-)-5'-noraristeromycin (50). All these compounds may be assumed to act as SAH hydrolase inhibitors (51) and should be further explored for their potential as anti-EBOV drug candidates.

\section{FAVIPIRAVIR (T-705) (Fig. 6)}

Favipiravir is the only pyrazine compound shown to be antivirally active $(52,53)$. It is active against both (-)RNA

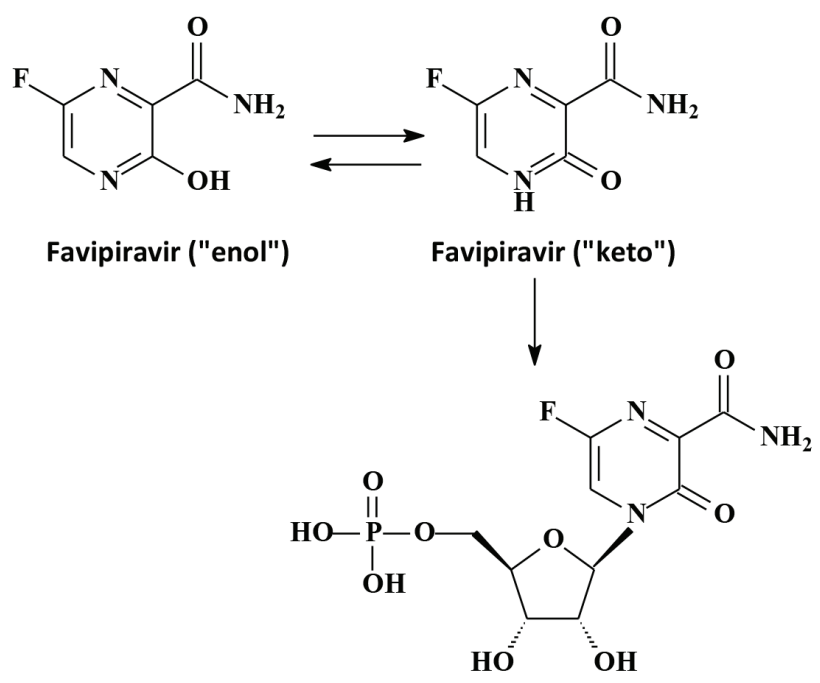

Favipiravir ribose-5'-monophosphate<smiles>C[14CH2]c1cn([C@@H]2O[C@H](COP(=O)(O)OP(=O)(O)OP(=O)(O)O)[C@@H](O)[C@H]2O)c(=O)c(C(N)=O)n1</smiles>

Favipiravir ribose-5'-triphosphate

Fig. 6. Favipiravir and its metabolites. 
<smiles>Nc1ncnc2c(C3NC(CO)[C@H](O)C3O)c[nH]c12</smiles>

Fig. 7. BCX4430.

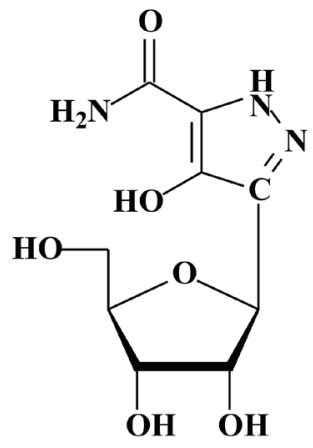

Fig. 8. Pyrazofurin viruses (i.e. orthomyxo-, paramyxo-, arena-, bunya-, hantaviruses) and (+)RNA viruses (flavi-, picorna- and noroviruses). Although its potential activity against rhabdoviridae (rabies, VSV) was not assessed, it was shown to be efficacious in vivo, in mice, against EBOV infection $(54,55)$. The compound (trade name: Avigan ${ }^{\circledR}$ ) has been approved in Japan for the treatment of influenza A virus infections, and be made available in (sufficiently ?) large quantities for the treatment of EBOV infection in West Africa. Favipiravir is assumed to be targeted at the viral RNA polymerase. To this end, the compound should be converted by a phosphoribosyl transferase (similar to orotinic acid, adenine and hypoxanthine-guanine) to its ribosylmonophosphate, and then converted to its triphosphate, before interacting at the viral RNA polymerase, presumably in direct competition with GTP.

\section{BCX4430 (Fig. 7)}

As mentioned by Warren et al. (56), BCX4430, a $\mathrm{C}$-nucleoside, was synthesized as part of a small-molecule library designed as inhibitors of viral RNA polymerase activity. BCX4430 would inhibit viral RNA polymerase through a non-obligate RNA chain termination, obviously after its (intracellular) phosphorylation to BCX 4430 triphosphate. BCX4430 proved particularly active against picorna-, flavi-, orthomyxo-, paramyxo- and filoviruses (its activity against rhabdoviruses such as VSV was, unfortunately, not determined). In vivo, BCX4430 completely protected cynomolgus macaques against Marburg virus infection, and claimed to be the first compound shown to protect non-human primates from a filovirus infection (56). This may herald potential efficacy in the treatment of EBOV infection in humans. BCX4430 has also been shown to offer complete protection from mortality in hamsters infected with yellow fever virus (57).

\section{Pyrazofurin (Fig. 8)}

Pyrazofurin, a C-nucleoside, was found to be extremely potent against VSV, irrespective of the cell culture used: primary rabbit kidney (PRK) (MIC: $0.01 \mu \mathrm{g} / \mathrm{ml}$ ), human skin fibroblast (HSF) (MIC: $0.04 \mu \mathrm{g} / \mathrm{ml}$ ) and HeLa (MIC: $0.02 \mu \mathrm{g} / \mathrm{ml}$ ) (58). Pyrazofurin was about 1,000-fold more potent against VSV than ribavirin. However, its efficacy against VSV in vivo could not be assessed as the compound proved too toxic to mice: its $50 \%$ lethal dose $\left(\mathrm{LD}_{50}\right)$ was approximately $5 \mathrm{mg} / \mathrm{kg}$ per day. This in vivo toxicity also hampered the further evaluation of pyrazofurin against murine leukemia virus, which, like VSV, appeared exquisitely sensitive (MIC: $0.01 \mu \mathrm{g} / \mathrm{ml}$ ) to inhibition by pyrazofurin (59). Pyrazofurin (originally named pyrazomycin) has since long been shown to inhibit de novo pyrimidine mononucleotide biosynthesis at the level of orotidylic acid (OMP) decarboxylase (which converts OMP to UMP) $(60,61)$.

\section{EBOV INHIBITORS INTERACTING WITH VIRAL ENTRY (Fig. 9)}

Mannose-specific lectins

Griffithsin and similar lectins that bind to the terminal mannose residues of the glycoproteins may be potentially useful in the treatment of EBOV infections $(62,63)$.

Endoplasmic reticulum (ER) glucosidase inhibitors

The imino sugar 1-deoxynojirimycin is a glucose mimic, with a nitrogen atom replacing the oxygen, that inhibits the ER $\alpha$-glucosidases I and II, which are essential in the maturation of viral envelope glycoproteins (64). Its derivatives IHVR11029, IHVR17028 and IHVR19029 were shown to protect mice against the mortality of Marburg and EBOV infections (65).

Benzylpiperazine adamantane diamides

EBOV entry into the host cells requires the cholesterol transporter Niemann-Pick C1 (66), and this process can be blocked by benzylpiperazine adamantane diamides (67).

Rhodamine derivatives

The rhodamine derivative LJ-001 inhibits the cell entry of 
<smiles>OC[C@H]1[C@@H](O)C(O)[C@@H](O)CN1CCCCCCOc1cc(F)ccc1F</smiles><smiles>CC(C)(C)C(=O)N(CCCCCCN1C[C@H](O)C(O)[C@H](O)[C@H]1CO)C1CCCCC1</smiles><smiles>CC(C)(C)NC(=O)N(CCCCCCN1CC(O)C(O)[C@H](O)[C@H]1CO)C1CCCCC1</smiles><smiles>O=C(CC12CC3CC(CC(C3)C1)C2)NCC(=O)N1CCN(Cc2ccccc2)CC1</smiles><smiles>NC(=O)c1ccc(COc2ccccc2CN2CCN(C(=O)CNC(=O)CC34CC5CC(CC(C5)C3)C4)CC2)cc1</smiles><smiles>C=CCN1C(=O)/C(=C/c2ccc(-c3ccccc3)o2)SC1=S</smiles><smiles>CCN(CC)CCOc1ccc(C(=C(Cl)c2ccccc2)c2ccccc2)cc1</smiles><smiles>CN(C)CCOc1ccc(C(=C(CCCl)c2ccccc2)c2ccccc2)cc1</smiles><smiles>CCCCc1oc2ccccc2c1C(=O)c1cc(I)c(OCCN(CC)CC)c(I)c1</smiles><smiles>CCCCc1oc2ccc(NSOC)cc2c1C(=O)c1ccc(OCCCN(CCCC)CCCC)cc1</smiles><smiles>COc1ccc(CCN([W])CCCC(C#N)(c2ccc(OC)c(OC)c2)C(C)C)cc1OC</smiles>

Fig. 9. Miscellaneous compounds inhibiting EBOV entry. 
various enveloped viruses such as influenza A, HIV, pox-, arena-, bunya-, paramyxo-, flavi- and filoviruses, including EBOV (68).

\section{Selective estrogen receptor modulators (SERMS)}

SERMS (i.e. clomifene and toremifene), through an offtarget, interfere with a late step of EBOV entry, thereby preventing the fusion process (69).

\section{Ion channel blockers}

The ion channel blockers amiodarone, dronedarome and verapamil were found to inhibit the cell entry of filoviruses (i.e. EBOV) (70) at the concentrations required for antiarrhythmic therapy in humans (i.e. $1.5-2.5 \mu \mathrm{g} / \mathrm{ml}$ ).

\section{CHLOROQUINE (Fig. 10)}

Chloroquine has been known since 1934 as an anti-malaria agent. Concomitantly with, and subsequently to, the emergence of HIV, SARS coronavirus and finally EBOV, chloroquine was shown to inhibit HIV (71), SARS coronavirus (72), and EBOV (73). It inhibits both the endocytosis and exocytosis of virus particles, and in addition, downregulates IFN- $\gamma$ and TNF- $\alpha$ production (74).

\section{CONCLUSIONS}

Furtherst advanced in the treatment of EBOV infections is favipiravir (T-705), also because its human use has proved safe and efficacious in the treatment of influenza virus infections. It is targeted at the viral RNA polymerase; although effective against (+)RNA and (-)RNA viruses, its activity against the (-)RNA rhabdoviruses (i.e. VSV) has not been assessed. The latter is true for $\mathrm{BCX} 4430$ as well, which in addition is a C-nucleoside, for which the safety/ toxicity profile in humans remains to be ascertained. Plenty of $\underline{\mathrm{S} \text {-adenosylhomocysteine hydrolase (SAH) inhibitors }}$ have been shown to be highly active against VSV, and one of them, 3-deazaneplanocin A, has also been shown to be effective against EBOV. Pyrazofurin is an highly potent

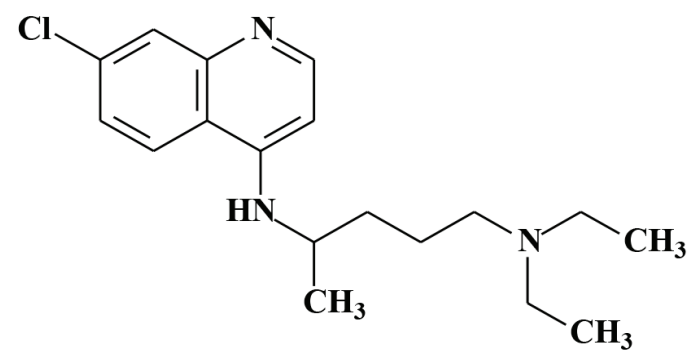

Fig. 10. Chloroquine (Nivaquine).

inhibitor of VSV, but its activity against EBOV has not been evaluated. Like BCX4430, pyrazofurin is a $\mathrm{C}$-nucleoside, which may be considered as a liability for its therapeutic (antiviral) usefulness. Ribavirin and other IMP dehydrogenase inhibitors may not seem particularly effective against VSV and EBOV. C-Cyd and Ce-Cyd are sufficiently active against VSV to be further evaluated for their potential activity against EBOV. This suggestion should also be extended to the sulfated polysaccharides which have proved quite effective in vitro against VSV, never evaluated against EBOV, but, once upon a time, considered for their potential in the treatment of HIV infections. Being a prodrug of cidofovir, there is no rationale whatsoever for the activity of brincidofovir (CMX001) against EBOV. Given its historically founded activity against VSV, interferon should be entertained for the treatment of EBOV infections. In the meantime, numerous compounds licensed for the most disparate clinical indications have been found to interfere with the cell entry of EBOV. And the list of antiviral drugs to be envisaged for their potential use against EBOV should be incomplete if it were not finalized by chloroquine.

\section{ACKNOWLEDGMENTS}

I am most grateful to Mrs. Christiane Callebaut for her proficient editorial assistance. 


\section{EBOV enfeksiyonlarının tedavisi amacıyla ilaç geliştirme sürecinde VSV örneği}

\section{ÖZET}

İnsanlarda görülen Ebola virüs (EBOV) enfeksiyonlarının tedavisinde kullanılmak üzere bir antiviral ilaç henüz sağlık otoritelerince onaylanmamıştır. $\mathrm{Bu}$ amaçla kullanılmak üzere onaylanmaya en yakın olan ilaç bir viral RNA polimeraz inhibitörü olan favipiravir (T-705)'tir. Üzerinde çalışılan diğer bileşikler ise bir viral RNA polimeraz inhibitörü olan BCX4430 ve S-adenosilhomosistein (SAH) hidrolaz inhibitörü olan 3-deazaneplanosin A'dır. Diğer endikasyonlar için onaylanan bileşiklerden Ebola virüs (EBOV) enfeksiyonlarının tedavisinde kullanılmak üzere denenenlerin ise Ebola virüs'ün hücre penetrasyon faktörleri ile etkileştiği gözlenmiştir. Pirazofurin gibi bazı bileşiklerin ise veziküler stomatitis virüs'ün (VSV) potansiyel inhibitörleri olduğu tespit edilmiştir. VSV, rhabdoviridae ailesine ait bir virüstür ve bu virüs ailesi EBOV ve Marburg virüs'ünün mensubu olduğu filoviridae virüs ailesi ile yüksek oranda benzerlik göstermektedir. EBOV ve Marburg virüs'ü biyogüvenlik derecesi 4 oranında çalışma güvenliği gerektirirken VSV ile mutat güvenlik koşullarında çalışılabilmektedir.

Anahtar Kelimeler: Ebola virüs (EBOV); veziküler stomatitis virüs (VSV); rhabdoviridae; filoviridae; favipiravir; BCX4430; pirazofurin; SAH hidrolaz

\section{REFERENCES}

1. Isaacs A, Lindenmann J. Virus interference. I. Interferon. Proc Royal Soc London 1957;147: 258-67.

2. Pattyn S, Jacob W, van der Groen G, Piot P, Courteille G. Isolation of Marburg-like virus from a case of haemorrhagic fever in Zaire. Lancet 1977;309: 573-4.

3. De Clercq E, De Somer P. Protective effect of interferon and polyacrylic acid in newborn mice infected with a lethal dose of vesicular stomatitis virus. Life Sci 1968;7: 925-33.

4. Haagmans BL, Kuiken T, Martina BE, Fouchier RA, Rimmelzwaan GF, van Amerongen G, van Riel D, de Jong T, Itamura S, Chan KH, Tashiro M, Osterhaus AD. Pegylated interferon-alpha protects type 1 pneumocytes against SARS coronavirus infection in macaques. Nat Med 2004;10: 290-3.

5. Smith LM, Hensley LE, Geisbert TW, Johnson J, Stossel A, Honko A, Yen JY, Geisbert J, Paragas J, Fritz E, Olinger G, Young HA, Rubins KH, Karp CL. Interferon- $\beta$ therapy prolongs survival in rhesus macaque models of Ebola and Marburg hemorrhagic fever. J Infect Dis 2013;208: 310-8.

6. Baba M, Snoeck R, Pauwels R, De Clercq E. Sulfated polysaccharides are potent and selective inhibitors of various enveloped viruses, including herpes simplex virus, cytomegalovirus, vesicular stomatitis virus, and human immunodeficiency virus. Antimicrob Agents Chemother 1988;32: 1742-5.

7. Ito M, Baba M, Hirabayashi K, Matsumoto T, Suzuki M, Suzuki S, Shigeta S, De Clercq E. In vitro activity of mannan sulfate, a novel sulfated polysaccharide, against human immunodeficiency virus type 1 and other enveloped viruses. Eur J Clin Microbiol 1989;8: 171-3.

8. Baba M, Nakajima M, Schols D, Pauwels R, Balzarini J, De Clercq E. Pentosan polysulfate, a sulfated oligosaccharide, is a potent and selective anti-HIV agent in vitro. Antiviral Res 1988;9: 335-43.
9. Ueno R, Kuno S. Dextran sulphate, a potent anti-HIV agent in vitro having synergism with zidovudine. Lancet 1987;i: 1379 .

10. Ito M, Baba M, Sato A, Pauwels R, De Clercq E, Shigeta S. Inhibitory effect of dextran sulfate and heparin on the replication of human immunodeficiency virus (HIV) in vitro. Antiviral Res 1987;7: 361-7.

11. Baba M, Pauwels R, Balzarini J, Arnout J, Desmyter J, De Clercq E. Mechanism of inhibitory effect of dextran sulfate and heparin on replication of human immunodeficiency virus in vitro. Proc Natl Acad Sci USA 1988;85: 6132-6.

12. Mitsuya H, Looney DJ, Kuno S, Ueno R, Wong-Staal F, Broder S. Dextran sulfate suppression of viruses in the HIV family: inhibition of virion binding to CD4+ cells. Science 1988;240: 646-9.

13. Schols D, De Clercq E, Balzarini J, Baba M, Witvrouw M, Hosoya M, Andrei G, Snoeck R, Neyts J, Pauwels R, Nagy M, Györgyi-Edelényi J, Machovich R, Horváth I, Löw M, Görög S. Sulphated polymers are potent and selective inhibitors of various enveloped viruses, including herpes simplex virus, cytomegalovirus, vesicular stomatitis virus, respiratory syncytial virus, and toga-, arena- and retroviruses. Antivir Chem Chemother 1990;1: 233-40.

14. Witvrouw M, Desmyter J, De Clercq E. Antiviral portrait series: 4. Polysulfates as inhibitors of HIV and other enveloped viruses. Antivir Chem Chemother 1994;5: 345-59.

15. Witvrouw M, Este JA, Mateu MQ, Reymen D, Andrei G, Snoeck R, Ikeda S, Pauwels R, Bianchini NV, Desmyter J, De Clercq E. Activity of a sulfated polysaccharide extracted from the red seaweed Aghardhiella tenera against human immunodeficiency virus and other enveloped viruses. Antivir Chem Chemother 1994;5: 297-303.

16. Witvrouw M, De Clercq E. Sulfated polysaccharides extracted from sea algae as potential antiviral drugs. Gen Pharmacol 1997;29: 497-511. 
17. Witvrouw M, Fikkert V, Pluymers W, Matthews B, Mardel K, Schols D, Raff J, Debyser Z, De Clercq E, Holan G, Pannecouque C. Polyanionic (i.e., polysulfonate) dendrimers can inhibit the replication of human immunodeficiency virus by interfering with both virus adsorption and later steps (reverse transcriptase/integrase) in the virus replicative cycle. Mol Pharmacol 2000;58: 1100-8.

18. Witkowski JT, Robins RK, Sidwell RW, Simon LN. Design, synthesis, and broad spectrum antiviral activity of $1-\beta-\mathrm{D}-$ ribofuranosyl-1,2,4-triazole-3-carboxamide and related nucleosides. J Med Chem 1972; 15: 1150-4.

19. Sidwell RW, Huffman JH, Khare GP, Allen LB, Witkowski JT, Robins RK. Broad-spectrum antiviral activity of Virazole: 1-beta-D-ribofuranosyl-1,2,4-triazole-3-carboxamide. Science 1972;177: 705-6.

20. Streeter DG, Witkowski JT, Khare GP, Sidwell RW, Bauer RJ, Robins RK, Simon LN. Mechanism of action of 1- $\beta$-Dribofuranosyl-1,2,4-triazole-3-carboxamide (Virazole), a new broad-spectrum antiviral agent. Proc Natl Acad Sci USA 1973;70: 1174-8.

21. De Clercq E, Luczak M, Reepmeyer JC, Kirk KL, Cohen LA. Fluoroimidazoles as antiviral agents and inhibitors of polynucleotide biosynthesis. Life Sci 1975;17: 187-94.

22. Huggins JW. Prospects for treatment of viral hemorrhagic fevers with ribavirin, a broad-spectrum antiviral drug. Rev Infect Dis 1989;11: S750-61.

23. De Clercq E, Cools M, Balzarini J, Snoeck R, Andrei G, Hosoya M, Shigeta S, Ueda T, Minakawa N, Matsuda A. Antiviral activities of 5-ethynyl-1-beta-Dribofuranosylimidazole-4-carboxamide and related compounds. Antimicrob Agents Chemother 1991;35: 679-84.

24. Matsuda A, Minakawa N, Sasaki T, Ueda T. The design, synthesis and antileukemic activity of 5-alkynyl-1-beta-Dribofuranosylimidazole-4-carboxamides. Chem Pharm Bull 1988;36: 2730-3.

25. Balzarini J, Karlsson A, Wang L, Bohman C, Horská K, Votruba I, Fridland A, Van Aerschot A, Herdewijn P, De Clercq E. EICAR (5-ethynyl-1-beta-Dribofuranosylimidazole-4-carboxamide). A novel potent inhibitor of inosinate dehydrogenase activity and guanylate biosynthesis. J Biol Chem 1993;268: 24591-8.

26. De Clercq E, Bernaerts R, Shealy YF, Montgomery JA. Broad-spectrum antiviral activity of carbodine, the carbocyclic analogue of cytidine. Biochem Pharmacol 1990;39: 319-25.

27. De Clercq E, Murase J, Marquez VE. Broad-spectrum antiviral and cytocidal activity of cyclopentenylcytosine, a carbocyclic nucleoside targeted at CTP synthetase. Biochem Pharmacol 1991;41: 1821-9.

28. Schabel FM Jr. The antiviral activity of 9- $\beta$-Darabinofuranosyladenine (Ara-A). Chemotherapy 1968;13: 321-38.

29. Adenine Arabinoside: An Antiviral Agent, eds. Pavan-
Langston D, Buchanan RA, Alford CA, Raven Press, NY, 1975, p 425.

30. De Clercq E, Descamps J, Krajeswka E, Shugar D. Antiviral activity of $\mathrm{O}$ '-methylated derivatives of adenine arabinoside. Biochem Pharmacol 1977;26: 794-7.

31. De Clercq E, Descamps J, De Somer P, Holý A. (S)-9-(2,3Dihydroxypropyl)adenine: an aliphatic nucleoside analog with broad-spectrum antiviral activity. Science 1978;200: 563-5.

32. De Clercq E, Montgomery JA. Broad-spectrum antiviral activity of the carbocyclic analog of 3-deazaadenosine. Antiviral Res 1983;3: 17-24.

33. De Clercq E, Cools M. Antiviral potency of adenosine analogues: correlation with inhibition of S-adenosylhomocysteine hydrolase. Biochem Biophys Res Commun 1985;129: 306-11.

34. De Clercq E, Bergstrom DE, Holý A, Montgomery JA. Broad-spectrum antiviral activity of adenosine analogues. Antiviral Res 1984;4: 119-33.

35. Bergstrom DE, Brattesani AJ, Ogawa MK, Reddy PA, Schweickert MJ, Balzarini J, De Clercq E. Antiviral activity of C-5 substituted tubercidin analogues. J Med Chem 1984;27: 285-92.

36. Giziewicz J, De Clercq E, Luczak M, Shugar D. Antiviral and antimetabolic activities of formycin and its N1-, N2-, 2'-Oand 3'-O-methylated derivatives. Biochem Pharmacol 1975;24: 1813-7.

37. De Clercq E, Balzarini J, Madej D, Hansske F, Robins MJ. Nucleic acid related compounds. 51. Synthesis and biological properties of sugar-modified analogues of the nucleoside antibiotics tubercidin, toyocamycin, sangivamycin, and formycin. J Med Chem 1987;30: 481-6.

38. De Clercq E. Antiviral and antimetabolic activities of neplanocins. Antimicrob Agents Chemother 1985;28: 84-9.

39. De Clercq E, Cools M, Balzarini, J, Marquez VE, Borcherding DR, Borchardt RT, Drach JC, Kitaoka S, Konno T. Broadspectrum antiviral activities of neplanocin $A$, 3-deazaneplanocin A, and their 5'-nor derivatives. Antimicrob Agents Chemother 1989;33: 1291-7.

40. Cools M, De Clercq E. Correlation between the antiviral activity of acyclic and carbocyclic adenosine analogues in murine L929 cells and their inhibitory effect on L929 cells S-adenosylhomocysteine hydrolase. Biochem Pharmacol 1989;38: 1061-7.

41. De Clercq E. S-adenosylhomocysteine hydrolase inhibitors as broad-spectrum antiviral agents. Biochem Pharmacol 1987;36: 2567-75.

42. Bray M, Driscoll J, Huggins JW. Treatment of lethal Ebola virus infection in mice with a single dose of an S-adenosyl-Lhomocysteine hydrolase inhibitor. Antiviral Res 2000;45: 135-47.

43. Bray M, Raymond JL, Geisbert T, Baker RO. 3-Deazaneplanocin A induces massively increased 
interferon- $\alpha$ production in Ebola virus-infected mice. Antiviral Res 2002;55: 151-9.

44. Patil SD, Schneller SW, Hosoya M, Snoeck R, Andrei G, Balzarini J, De Clercq,, E. Synthesis and antiviral properties of $( \pm)-5$ '-noraristeromycin and related purine carbocyclic nucleosides. A new lead for anti-human cytomegalovirus agent design. J Med Chem 1992;35: 3372-7.

45. Siddiqi SM, Chen X, Schneller SW, Ikeda S, Snoeck R, Andrei G, Balzarini J, De Clercq E. Antiviral enantiomeric preference for 5'-noraristeromycin. J Med Chem 1994;37: 551-4.

46. Siddiqi SM, Chen X, Rao J, Schneller SW, Ikeda S, Snoeck R, Andrei G, Balzarini J, De Clercq, E. 3-deaza- and 7-deaza5 '-noraristeromycin and their antiviral properties. J Med Chem 1995;38: 1035-8.

47. Shuto S, Obara T, Toriya M, Hosoya M, Snoeck R, Andrei G, Balzarini J, De Clercq E. New neplanocin analogues. 1. Synthesis of 6'-modified neplanocin A derivatives as broadspectrum antiviral agents. J Med Chem 1992;35: 324-31.

48. Shuto S, Obara T, Saito Y, Yamashita K, Tanaka M, Sasaki T, Andrei G, Snoeck R, Neyts J, Padalko E, Balzarini J, De Clercq E, Matsuda A. New neplanocin analogues. VIII. Synthesis and biological activity of 6'-C-ethyl, -ethenyl, and -ethynyl derivatives of neplanocin A. Chem Pharm Bull 1997;45: 1163-8.

49. Cools M, Balzarini J, De Clercq, E. Mechanism of antiviral and cytotoxic action of $( \pm)-6$ ' beta-fluoroaristeromycin, a potent inhibitor of S-adenosylhomocysteine hydrolase. Mol Pharmacol 1991;39: 718-24.

50. Siddiqi SM, Chen X, Schneller SW, Ikeda S, Snoeck R, Andrei G, Balzarini J, De Clercq E. An epimer of 5 '-norartisteromycin and its antiviral properties. J Med Chem 1994;37: 1382-4.

51. De Clercq E. John Montgomery's legacy: carbocyclic adenosine analogues as SAH hydrolase inhibitors with broadspectrum antiviral activity. Nucleosides Nucleotides Nucleic Acids 2005;24: 1395-1415.

52. De Clercq E. A cutting-edge view on the current state of antiviral drug development. Med Res Rev 2013;33: 1249-77.

53. De Clercq E. Dancing with chemical formulae of antivirals: A panoramic view (Part 2). Biochem Pharmacol 2013;86: 13971410.

54. Smither SJ, Eastaugh LS, Steward, JA, Nelson M, Lenk RP, Lever MS. Post-exposure efficacy of oral T-705 (favipiravir) against inhalational Ebola virus infection in a mouse model. Antiviral Res 2014;104: 153-5.

55. Oestereich L, Lüdtke A, Wurr S, Rieger T, Munoz-Fontela C, Günther S. Successful treatment of advanced Ebola virus infection with T-705 (favipiravir) in a small animal model. Antiviral Res 2014;105: 17-21.

56. Warren TK, Wells J, Panchal RG, Stuthman KS, Garza NL, Van Tongeren SA, Dong L, Retterer CJ, Eaton BP, Pegoraro G, Honnold S, Bantia S, Kotian P, Chen X, Taubenheim BR,
Welch LS, Minning DM, Babu YS, Sheridan WP, Bavari S. Protection against filovirus diseases by a novel broadspectrum nucleoside analogue BCX4430. Nature 2014;508: 402-5.

57. Julander JG, Bantia S, Taubenheim BR, Minning DM, Kotian P, Morrey JD, Smee DF, Sheridan WP, Babu YS. BCX4430, a novel nucleoside analog, effectively treats yellow fever in a hamster model. Antimicrob Agents Chemother 2014;58: 6607-14.

58. Descamps J, De Clercq E. Broad-spectrum antiviral activity of pyrazofurin (pyrazomycin). Curr Chemother 1978; 354-7.

59. Shannon WM. Selective inhibition of RNA tumor virus replication in vitro and evaluation of candidate antiviral agents in vivo. Ann NY Acad Sci 1977;284: 472-507.

60. Gutowski GE, Sweeney MJ, DeLong DC, Hamill RL, Gerzon $\mathrm{K}$. Biochemistry and biological effects of the pyrazofurins (pyrazomycins): initial clinical trial. Ann NY Acad Sci 1975;255: 544-51.

61. Sweeney MJ, Davis FA, Gutowski GE, Hamill RL, Hoffman DH, Poore GA. Experimental antitumor activity of pyrazomycin. Cancer Res 1973;33: 2619-23.

62. Barton C, Kouokam JC, Lasnik AB, Foreman O, Cambon A, Brock G, Montefiori DC, Vojdani F, McCormick AA, O'Keefe BR, Palmer KE. Activity of and effect of subcutaneous treatment with the broad-spectrum antiviral lectin griffithsin in two laboratory rodent models. Antimicrob Agents Chemother 2014;58: 120-7.

63. Balzarini J, Van Laethem K, Hatse S, Vermeire K, De Clercq E, Peumans W, Van Damme E, Vandamme AM, Bölmstedt A, Schols D. Profile of resistance of human immunodeficiency virus to mannose-specific plant lectins. J Virol 2004;78: 10617-27.

64. Dwek RA, Butters TD, Platt FM, Zitzmann N. Targeting glycosylation as a therapeutic approach. Nat Rev Drug Discov 2002; 1: 65-75.

65. Chang J, Warren TK, Zhao X, Gill T, Guo F, Wang L, Comunale MA, Du Y, Alonzi DS, Yu W, Ye H, Liu F, Guo JT, Mehta A, Cuconati A, Butters TD, Bavari S, Xu X, Block TM. Small molecule inhibitors of ER $\alpha$-glucosidases are active against multiple hemorrhagic fever viruses. Antiviral Res 2013;98: 432-40.

66. Carette JE, Raaben M, Wong AC, Herbert AS, Obernosterer G, Mulherkar N, Kuehne AI, Kranzusch PJ, Griffin AM, Ruthel G, Dal Cin P, Dye JM, Whelan SP, Chandran K, Brummelkamp TR. Ebola virus entry requires the cholesterol transporter Niemann-Pick C1. Nature 2011;477: 340-3.

67. Côté M, Misasi J, Ren T, Bruchez A, Lee K, Filone CM, Hensley L, Li Q, Ory D, Chandran K, Cunningham J. Small molecule inhibitors reveal Niemann-Pick C1 is essential for Ebola virus infection. Nature 2011;477: 344-8.

68. Wolf MC, Freiberg AN, Zhang T, Akyol-Ataman Z, Grock A, Hong PW, Li J, Watson NF, Fang AQ, Aguilar HC, Porotto M, Honko AN, Damoiseaux R, Miller JP, Woodson SE, 
Chantasirivisal S, Fontanes V, Negrete OA, Krogstad P, Dasgupta A, Moscona A, Hensley LE, Whelan SP, Faull KF, Holbrook MR, Jung ME, Lee B. A broad-spectrum antiviral targeting entry of enveloped viruses. Proc Natl Acad Sci U S A 2010;107: 3157-62.

69. Johansen LM, Brannan JM, Delos SE, Shoemaker CJ, Stossel A, Lear C, Hoffstrom BG, Dewald LE, Schornberg KL, Scully C, Lehár J, Hensley LE, White JM, Olinger GG. FDAapproved selective estrogen receptor modulators inhibit Ebola virus infection. Sci Transl Med 2013;5: 190ra79.

70. Gehring G, Rohrmann K, Atenchong N, Mittler E, Becker S, Dahlmann F, Pöhlmann S, Vondran FW, David S, Manns MP, Ciesek S, von Hahn T. The clinically approved drugs amiodarone, dronedarone and verapamil inhibit filovirus cell entry. J Antimicrob Chemother 2014;69: 2123-31.
71. Savarino A, Gennero L, Sperber K, Boelaert JR. The antiHIV-1 activity of chloroquine. J Clin Virol 2001;20: 131-5.

72. Keyaerts E, Vijgen L, Maes P, Neyts J, Van Ranst M. In vitro inhibition of severe acute respiratory syndrome coronavirus by chloroquine. Biochem Biophys Res Commun 2004;323: 264-8.

73. Madrid PB, Chopra S, Manger ID, Gilfillan L, Keepers TR, Shurtleff AC, Green CE, Iyer LV, Dilks HH, Davey RA, Kolokoltsov AA, Carrion R Jr, Patterson JL, Bavari S, Panchal RG, Warren TK, Wells JB, Moos WH, Burke RL, Tanga MJ. A systematic screen of FDA-approved drugs for inhibitors of biological threat agents. PLoS One 2013;8: e60579.

74. Savarino A, Boelaert JR, Cassone A, Majori G, Cauda R. Effects of chloroquine on viral infections: an old drug against today's diseases? Lancet Infect Dis 2003;3: 722-7. 